\title{
К ВОПРОСУ О РУДНЫХ ФОРМАЦИЯХ БЛАГОРОДНЫХ И ЦВЕТНЫХ МЕТАЛЛОВ ОМОЛОНСКОГО ТЕРРЕЙНА (Северо-Восток Азии)*
}

\author{
Глухов А. Н. \\ ФГБУН Северо-Восточный комплексный научно-исследовательский институт \\ им. Н. А. Шило ДВО РАН, г. Магадан \\ E-mail: gluhov76@list.ru
}

\begin{abstract}
Охарактеризованы месторождения и рудопроявления $\mathrm{Au}, \mathrm{Ag}, \mathrm{Pb}, \mathrm{Cu}$, развитые в пределах Омолонского кратонного террейна. Намечены рудные формации, к которым они относятся. Показано, что главные черты металлогении террейна обусловлены его жесткой глыбовой структурой с кристаллическим фундаментом, консолидированным в дорифейское время. Это привело к сужению спектра рудных формаций, формированию протяженных глубинных магмо- и рудоконтролирующих разломов и формированию крупных по запасам месторождений.
\end{abstract}

Ключевые слова: кратонный террейн, металлогения, рудная формация, фундамент, консолидированный.

DOI: $10.34078 / 1814-0998-2021-3-18-33$

\section{ВВЕДЕНИЕ}

Террейны с континентальной корой (термин предложен С. Д. Соколовым, 2010) широко распространены в пределах орогенных поясов на всех континентах Земли. Как правило, в их составе присутствуют докембрийские комплексы, в том числе метаморфические. Помимо древнего возраста, эти террейны зачастую выделяются высокой насыщенностью рудными проявлениями.

На Северо-Востоке Азии наиболее ярким примером подобной региональной структуры является Омолонский кратонный террейн (далее OM) (рис. 1). В его внутреннем строении выделяются архейско-протерозойский фундамент и рифейско-мезозойский терригенно-карбонатный чехол, а также продукты фанерозойского окраинно-континентального магматизма, представленные тремя вулкано-плутоническими поясами: Кедонским (КВП), Олойским (ОВП), Охотско-Чукотским (ОЧВП). В краевых частях ОМ располагаются орогенные впадины, выполненные позднемезозойскими молассовыми отложениями. Стратифицированные комплексы прорваны крупными батолитами палеозойского и мелового возраста. Главными элементами тектоники кристаллического фундамента ОМ являются моноклинали и гранито-гнейсовые купола,

(C) Глухов А. Н., 2021

*Публикуется в порядке дискуссии. чехла - пологие моноклинали и брахисинклинали. Разрывные нарушения, включая глубинные разломы, представляют собой, главным образом, взбросы и сдвиги. Состав вещественных комплексов террейна и характер тектонических деформаций отражают его стабильную, консолидированную структуру, сформировавшуюся к началу рифея (Глухов, 2019). Последующие эпохи сжатия и растяжения существенно не изменили структурный рисунок.

ОМ характеризуется широким развитием рудной минерализации. В первую очередь, это золото-серебряные месторождения, которые уже 30 лет успешно осваиваются промышленностью. Среди них есть как крупные по запасам объекты (Кубака, Биркачан), так и мелкие (Ольча, Елочка, Бургали, Ирбычан, Сопка Кварцевая, Ороч). Крупными прогнозными ресурсами молибдена и меди характеризуются порфировые рудопроявления Вечернее, Хрустальное, Табор.

Ранее автором уже было рассмотрено влияние тектоники и геодинамической эволюции ОМ на структуру вмещаемых им рудных полей и месторождений (Глухов, 2019) и их продуктивность (Глухов, 2020). В данной работе сделана попытка рассмотреть влияние этих факторов на генезис минерализации и спектр рудных формаций. Это может способствовать лучшему пониманию факторов рудоконтроля докембрийских региональных структур и влияния на них геодинамических условий. 


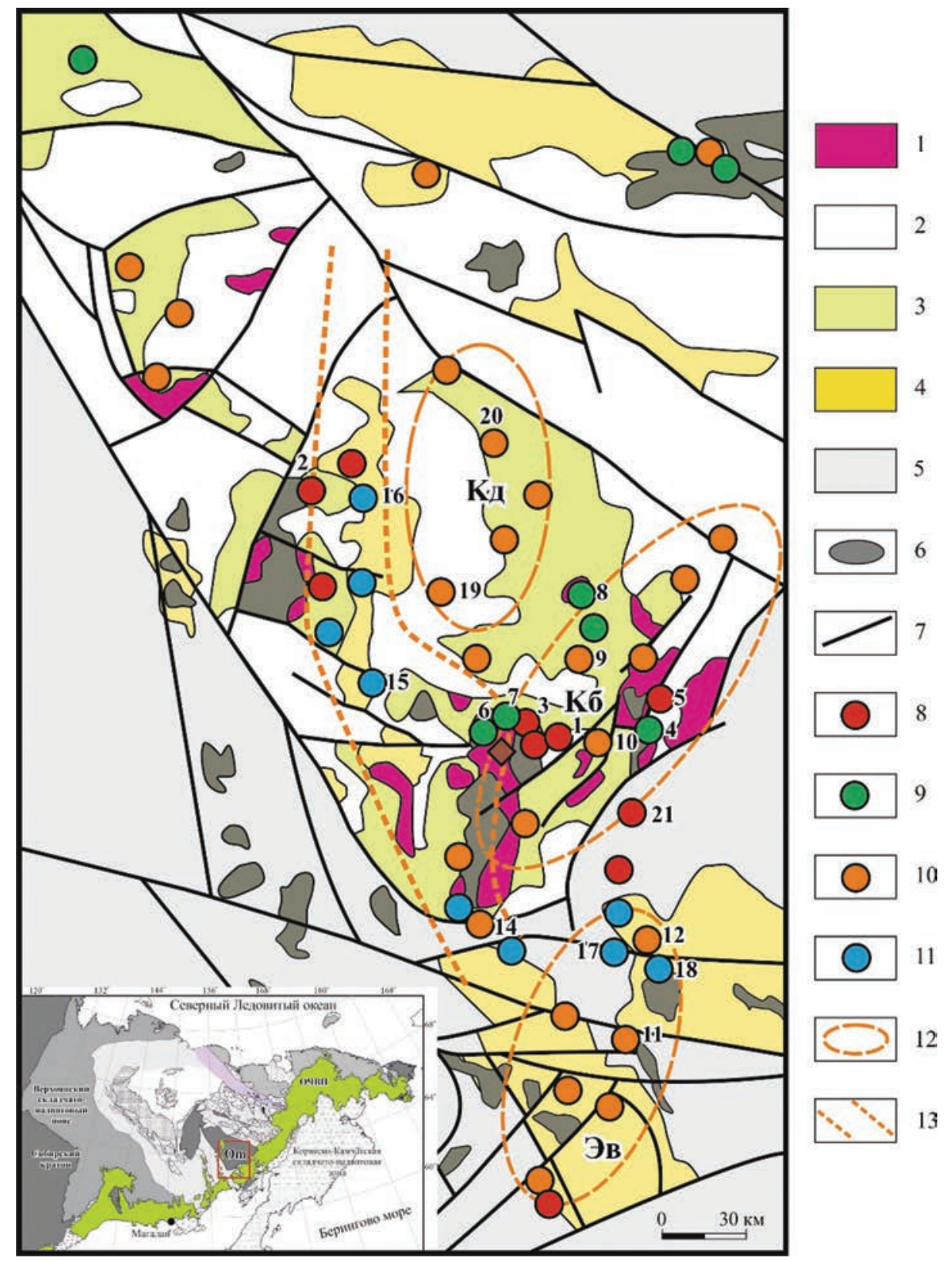

Puc. 1. Тектоно-минерагеническая схема Омолонского террейна (Глухов и др., 2021, с изменениями): 1дорифейский кристаллический фундамент; 2 - рифейско-среднеюрский и верхнеюрско-меловой структурный ярусы; 3, 4 - вулканогенные пояса (3 - Кедонский, 4 - Охотско-Чукотский и Олойский); 5 - террейны складчатого обрамления; 6 - гранитоиды; 7 - разломы; 8-11 - месторождения и рудопроявления различных формаций: 8 - золото-редкометалльной, 9 - медно-порфировой, 10 - золото-серебряной, 11 - серебро-полиметаллической; 12 - границы рудных районов (Кб - Кубакинского, Кд - Кедонского, Эв - Эвенского); 13 - границы Конгинской магматической зоны. Номерами обозначены месторождения, проявления и участки, упомянутые в тексте: 1 - Гриша, 2 - Джугаджак, 3 - Нодди, 4 - Табор, 5 - Орлиное, 6 - Вечернее, 7 - Хрустальное, 8 - Захаренко, 9 - Биркачан, 10 - Кубака, 11 - Ирбычан, 12 - Ороч, 13 - Сопка Кварцевая, 14 - Джелты, 15 - Седое, 16 - Вулкан, 17 - Дручак, 18 - Радуга, 19 - Юное, 20 - Рыжик, 21 - Горное, 22 - Нижний Биркачан, 23 - Невенрекан, 24 - Перекатное

Fig. 1. Tectonic and mineragenic scheme of the Omolon terrane (Glukhov et al., 2021 amended): 1 - Early Proterozoic crystalline basement; 2 - Upper Proterozoic, Jurassic, and Cretaceous sedimentary units; 3, 4 - volcanic belts (3 - Kedon, 4 - Okhotsk-Chukotka and Oloy); 5 - folded rim terranes; 6 - granitoids; 7 - faults; 8-11 - ore deposits and occurrences of different formations: 8 - gold-rare-metal, 9 - copper-porphyry, 10 - Au-Ag, 11 - silver-polymetallic; 12 - ore district boundaries (Кб - Kubaka, Кд - Kedon, Эв - Evensk); 13 - Kongina magmatic zone boundaries. Numbers of deposits: 1 - Grisha, 2 - Jugajak, 3 - Noddi, 4 - Tabor, 5 - Orlinoye, 6 - Vecherneye, 7 - Khrustalnoye, 8 -Zakharenko, 9 - Birkachan, 10 - Kubaka, 11 - Irbychan, 12 - Orotch, 13 - Sopka Kvartsevaya, 14 - Jelty, 15 - Sedoye, 16 - Vulcan, 17 - Druchak, 18 - Raduga, 19 - Yunoye, 20 - Rhyzhik, 21 - Gornoye, 22 - Nizhny Birkatchan, 23 - Nevenrekan, 24 - Perekatnoye 
К настоящему времени опубликовано несколько обобщающих исследований геологии и металлогении ОМ, содержащих геологогенетическую типизацию оруденения (Мерзляков и др., 1984; Шульгина и др., 1993; Шпикерман, 1998; Волков и др., 2011, 2016; Горячев и др., 2017; Савва, 2018). В работе А. В. Волкова с соавторами (2011) констатируется «слабая изученность рудных формаций» ОМ (С. 639) и выделены следующие типы благороднометалльного оруденения ОМ: $\mathrm{Cu}-\mathrm{Mo}-$ $\mathrm{Ag-порфировый,} \mathrm{Au}-\mathrm{Bi}-\mathrm{Te}$, связанный с интрузивами гранитоидов, Au-Ag эпитермальный и Au-Ag в джаспероидах. Н. А. Горячев с соавторами (2017) и Н. Е. Савва (2018) выделяют раннепалеозойское золото-кварцевое и молибденовое оруденение, среднепалеозойскую золото-серебряную формацию, формацию золото-сереброносных джаспероидов, меднопорфировое оруденение, золото-сульфиднокварцевое оруденение, серебро-арсенидную формацию, золоторудную минерализацию вулканогенно-осадочного генезиса, мезозойское золото-серебряное, медно-молибден-порфировое и серебро-полиметаллическое оруденение.

Наиболее широкий спектр формационных типов оруденения ОМ сформулирован А. А. Сидоровым с соавторами (2008). Сюда включены эпитермальный золото-серебряный, золото- и сереброносных джаспероидов, золото-сульфиднокварцевый, медно-молибден-порфировый, золото-теллуридный и скарновый. В. И. Шпикерман (1998) на ОМ выделил молибден-меднопорфировую, колчеданно-полиметаллическую, золото-серебряную и золото-джаспероидную формации.
При всех своих достоинствах упомянутые работы основаны на фактическом материале, полученном до 2000 г., а по большей части - в 19801990-х гг. Между тем в последние 20 лет благодаря большому объему геологоразведочных и научно-исследовательских работ выявлены новые рудные объекты, а информация о геологическом строении ранее известных существенно уточнена. В предыдущих публикациях нами были показаны некоторые особенности позднемезозойского металлогенического этапа ОМ, связанного с ОЧВП (Прийменко и др., 2020; Глухов и др., 2021). В основу данной работы положен фактический материал, собранный автором при исследованиях геологии и рудоносности ОМ в 2015-2018 гг. Большинство из упомянутых в тексте рудных объектов изучались автором лично; все они охарактеризованы большим количеством пробирных, спектральных (в том числе ICP), рентгеноспектральных анализов. Приводить их в статье нецелесообразно по причине ее обзорно-аналитической направленности. Некоторые сведения, вошедшие в данную статью, были опубликованы ранее (Глухов, 2019, 2020; Глухов и др., 2021).

В данной статье принято определение рудной формации П. А. Строны (1978): «...устойчивая естественная ассочиация месторождений, близких по генезису, минеральному составу, возрасту, формируюшихся в определенной геотектонической обстановке и обычно генетически, парагенетически связанных или хотя бы пространственно ассочиированных с той или иной геологической формаиией...» (С. 10). Определения рудных формаций, принятые при написании данной статьи, приведены в табл. 1.

Таблица 1. Принятая систематика рудных формаций Table 1. Systematics of ore Formations

\begin{tabular}{|c|c|c|c|}
\hline Рудная формация & Ссылка & Синоним & Ссылка \\
\hline Золото-кварцевая & Гамянин, 2001 & $\begin{array}{c}\text { Орогенные месторожде- } \\
\text { ния золота } \\
\end{array}$ & $\begin{array}{c}\text { Groves et al., 2003; } \\
\text { Горячев, } 2006\end{array}$ \\
\hline \multirow{2}{*}{$\begin{array}{l}\text { Золото-редкометалль- } \\
\text { ная }\end{array}$} & \multirow{2}{*}{ Гамянин, 2001} & $\begin{array}{c}\text { Аu-редкометалльно- } \\
\text { кварцевые жильные ме- } \\
\text { сторождения }\end{array}$ & Горячев, 2003 \\
\hline & & $\begin{array}{c}\text { Золотые месторождения, } \\
\text { связанные с гранито- } \\
\text { идами } \\
\end{array}$ & Groves et al., 2003 \\
\hline Золото-серебряная & $\begin{array}{l}\text { Петренко, 1999; } \\
\text { Гамянин, } 2001\end{array}$ & $\begin{array}{c}\text { Эпитермальные место- } \\
\text { рождения золота типа } \\
\text { Low-Sulfidation }\end{array}$ & Hedenquist et al., 2000 \\
\hline $\begin{array}{l}\text { Серебро-полиметал- } \\
\text { лическая }\end{array}$ & $\begin{array}{l}\text { Колесников и др., } \\
\text { 1999; Кравцова, } \\
2010\end{array}$ & - & - \\
\hline $\begin{array}{l}\text { Медно-молибден-порфи- } \\
\text { ровая }\end{array}$ & Сотников, 2006 & $\begin{array}{c}\text { Медно-порфировые } \\
\text { месторождения }\end{array}$ & $\begin{array}{c}\text { Павлова, 1978; Sillitoe, } \\
2009\end{array}$ \\
\hline
\end{tabular}




\section{РУДНОФОРМАЦИОННЫЙ АНАЛИЗ}

Месторождения и рудопроявления $\mathrm{Au}, \mathrm{Ag}, \mathrm{Cu}$, $\mathrm{Pb}, \mathrm{Zn}$ на ОМ имеют признаки, характерные для четырех рудных формаций (табл. 2).
$\mathrm{U}-\mathrm{Pb}$ датировок (SHRIMP) составляет от 375 до 369 млн лет (Акинин и др., 2020). На ТаборОрлином рудном поле (рис. 2,a) собственномедно-порфировая минерализация представлена зональным ореолом эпидот-хлоритовых пропи-

Таблица. 2. Рудные формации $\mathrm{Au}, \mathbf{A g}, \mathrm{Cu}, \mathrm{Pb}$ Омолонского террейна

Table 2. $\mathbf{A u}, \mathbf{A g}, \mathbf{C u}, \mathbf{P b}$ ore formations of the Omolon terrane

\begin{tabular}{|l|l|l|}
\hline \multicolumn{1}{|c|}{ Этап рудогенеза } & \multicolumn{1}{|c|}{ Рудная формация } & \multicolumn{1}{|c|}{ Примеры объектов } \\
\hline \multirow{5}{*}{ Позднемезозойский } & Золото-серебряная & Ирбычан, Эвенское, Джелты \\
\cline { 2 - 3 } & Золото-редкометалльная & Перекатное, Горное \\
\cline { 2 - 3 } & Серебро-полиметаллическая & Седое, Хивач, Вулкан \\
\cline { 2 - 3 } & Медно-молибден-порфировая & Вечернее, Хрустальное, Захаренко \\
\hline \multirow{2}{*}{$\begin{array}{c}\text { Средне-, позднепалео- } \\
\text { зойский }\end{array}$} & Золото-серебряная & Кубака, Биркачан, Нижний Биркачан \\
\cline { 2 - 3 } & Медно-молибден-порфировая & Табор, Орлиное \\
\cline { 2 - 3 } & Золото-редкометалльная & Нодди, Джугаджак \\
\hline
\end{tabular}

Проявления палеозойской золото-редкометалльной формации (Гриша, Джугаджак, Нодди), связанные с гранитоидами абкитского и анмандыканского комплексов, образуют Рассошинский рудный район, Абкитский, Джугаджакский и Ольдянинский рудные узлы. Рудные тела представлены крутопадающими жилами и прожилково-жильными зонами сульфиднокарбонат-кварцевого состава мощностью 25 м (Горячев и др., 2017). В рудах выделены три минеральные ассоциации, соответствующие трем этапам рудообразования (Горячев и др., 2017): золото-полисульфидно-гематитовая, золото-теллуридная, золото-серебряная. Содержания золота достигают десятков $\Gamma / \mathrm{T}$; геохимический спектр руд $\mathrm{Au}-\mathrm{Pb}-\mathrm{Ag}-(\mathrm{W}, \mathrm{Mo})-$ $\mathrm{Bi}-\mathrm{Zn}$-As. Некоторые рудопроявления сопровождаются россыпями золота. Имеющиеся определения возрастаминерализации ограничиваются Rb-Sr методом и неоднозначны: $1148 \pm$ 23 млн лет (Константинов и др., 2001) и $325 \pm$ 4.6 млн лет (Горячев и др., 2017). Генезис оруденения связывается с силурийскими коллизионными процессами (Шпикерман и др., 2001).

Золото-редкометалльная минерализация позднемезозойского возраста известна в связи с позднемеловыми гранитоидными интрузиями ОЧВП на южном фланге ОМ (Горное) и на его границе со складчатыми структурами обрамления (Перекатное; Прийменко и др., 2020). Она представлена сульфидно-турмалин-кварцевыми жилами и прожилками, зонами сульфидизированных турмалин-кварц-мусковитовых грейзенов с содержаниями золота до 2-10 г/т. Геохимический спектр минерализации $\mathrm{Au}-\mathrm{As}-\mathrm{Pb}-\mathrm{Ag}-\mathrm{Co}-\mathrm{Cu}$.

Позднепалеозойская медно-молибден-порфировая формация ОМ связана с гранитоидами КВП. На юге она приурочена к интрузиям гранитпорфиров и кварцевых диорит-порфиритов булунского комплекса. Их возраст по данным литов и кварц-слюдистых филлизитов, содержащих вкрапленность пирита, халькопирита, молибденита (рудопроявление Табор; рис. 3,a). Содержания меди достигают $0.7 \%$, молибдена 0.015 \% (В. Н. Егоров, 2000 г.). На удалении 12 км от медно-молибденового штокверка развиты крутопадающие жилы и прожилки сульфиднокарбонатно-кварцевого состава с гематитом, пиритом, халькопиритом, сфалеритом, галенитом, акантитом, сульфосолями серебра, самородным золотом (рудопроявление Орлиное; рис. 3,б). Содержания золота в жилах достигают 146 г/т, серебра - 1972 г/т, меди, свинца, цинка до $1 \%$. Геохимический спектр руд $\mathrm{Au}-\mathrm{Ag}-\mathrm{As}-(\mathrm{Pb}, \mathrm{Zn}$, $\mathrm{Cu})-\mathrm{Bi}$.

На севере ОМ, в пределах Ягоднинского рудного узла, медно-порфировая минерализация связана с гранитами и гранит-порфирами алыюряхского комплекса, имеющими возраст по результатам $\mathrm{Rb}-\mathrm{Sr}$ определения $321 \pm 8$ млн лет (Горячев и др., 2017). Сульфидно-кварцевые штокверки с пиритом, халькопиритом, галенитом, сфалеритом (Кораго, 1977) содержат меди до $0.3 \%$, свинца $-1 \%$, цинка $-0.5 \%$, золота -1 г/т, серебра - 20 г/т (Кораго, Лычагин, 1977).

Позднемезозойская медно-молибден-порфировая формачия ОМ связана с ОЧВП и ОВП. Порфировое оруденение ОЧВП контролируют позднемеловые интрузии гранитоидов викторинского интрузивного комплекса, имеющие U-Pb возраст по циркону (TIMS) 8687 млн лет (Глухов и др., 2021). На рудопроявлениях Вечернее и Хрустальное минерализация представлена сульфидно-кварцевыми штокверками и залежами оруденелых скарнов (Пак, 2002). Выделяются три минеральных парагенезиса: гранат-магнетитовый (скарновый), пиритарсенопирит-молибденит-полисульфидный, золото-серебро-теллуридно-висмутовый (Алексеенко и др., 1990; Горячев и др., 2017). Содержа- 

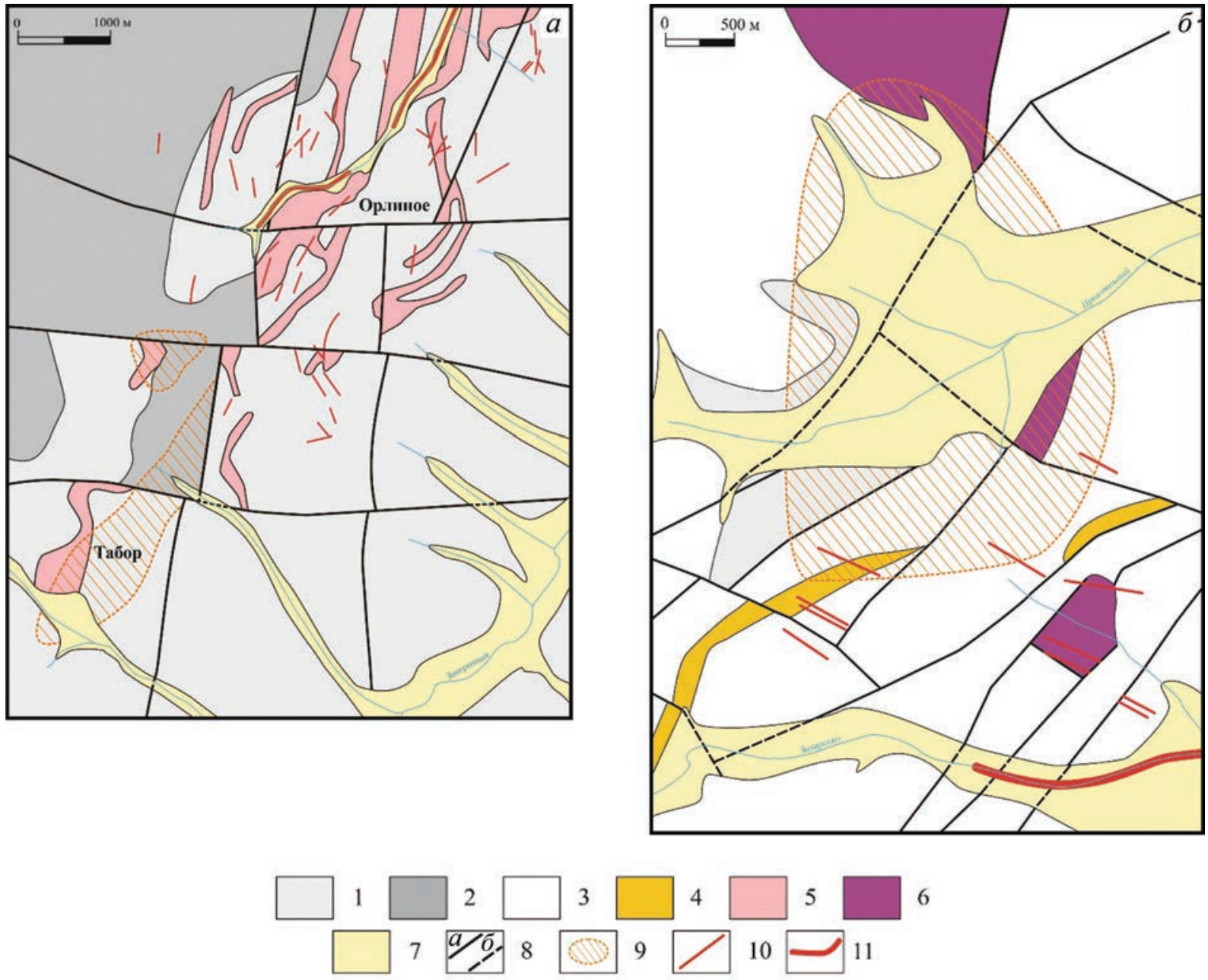

Puc. 2. Схемы геологического строения Табор-Орлиного (по Т. Б. Русаковой, 1991 г.) (a) и Захаренковского (по В. Н. Кудиенко, 2002 г.) (б) рудных полей: 1 - архейские гнейсы, амфиболиты и кальцифиры; 2 - диориты и гранодиориты абкитского интрузивного комплекса раннего палеозоя; 3 - туфы и игнимбриты риодацитов кедонской серии девона; 4 - экструзии и субвулканические тела риолитов кедонского комплекса; 5 - гранодиоритпорфиры булунского комплекса; 6 - гранодиориты и диорит-порфириты викторинского комплекса; 7 - четвертичные аллювиальные отложения; 8 - разломы достоверно установленные (a) и предполагаемые (б); 9 сульфидно-кварцевый штокверк с $\mathrm{Cu}-\mathrm{Mo} \mathrm{минерализацией;} 10$ - кварцевые жилы c $\mathrm{Au}-\mathrm{Ag}-\mathrm{Pb}$ минерализацией; 11 - россыпи золота

Fig. 2. Geological schemes of the Tabor-Orliny (after T. B. Rusakova, 1991) (a) and Zakharenko (after V. N. Kudienko, 2002) (б) ore fields: 1 - Archean gneisses and amphibolites; 2 - diorites and granodiorites of the Early Paleozoic Abkit igneous complex; 3 - rhyodacite tuffs and ignimbrites of the Devonian Kedon formation; 4 - extrusions and subvolcanic rhyolite bodies of the Kedon formation; 5 - granodiorite-porphyries of the Bulun complex; 6 - granodiorite and diorite-porphyries of the Victorinsky complex; 7 - Quaternary alluvial sediments; 8 - faults proved ( $a$ ), assumed (б); 9 - sulfide-quartz stockwork witn $\mathrm{Cu}-\mathrm{Mo}$ mineralization; 10 - quartz veins with $\mathrm{Au}-\mathrm{Ag}$ - $\mathrm{Pb}$ mineralization; 11 - gold placers

ния молибдена достигают $0.2 \%$, меди $-0.5 \%$, серебра -85 г/т, золота - 3.7 г/т. На Захаренковском рудном поле (см. рис. 2) Ar-Ar возраст штокверковой минерализации по серициту составил 88 млн лет (Глухов и др., 2021). Следует отметить, что мы относим рассматриваемую минерализацию именно к медно-молибден-порфировой формации, а не молибден-порфировой («тип Клаймакс»; Ludington, Plumlee, 2009). В пользу этого свидетельствуют монцонит-гранодиоритовый состав связанных с оруденением гранитоидов (Глухов и др., 2021), относящихся к I-типу (а не S- и
A-, как для собственно молибден-порфировых) и ассоциация с золото-серебряной и полиметаллической (а не олово-вольфрамовой) минерализацией. Высокие концентрации молибдена в рудах отражают сиалический состав рудовмещающих комплексов кристаллического фундамента Омолонского террейна.

На периферии медно-молибденовые штокверки (рис. 3, в) сменяются кварцевыми жилами с золото-серебро-полиметаллической минерализацией (рис. 3, г). На упомянутом Захаренковском рудном поле (см. рис. 2, б), где они содержат га- 

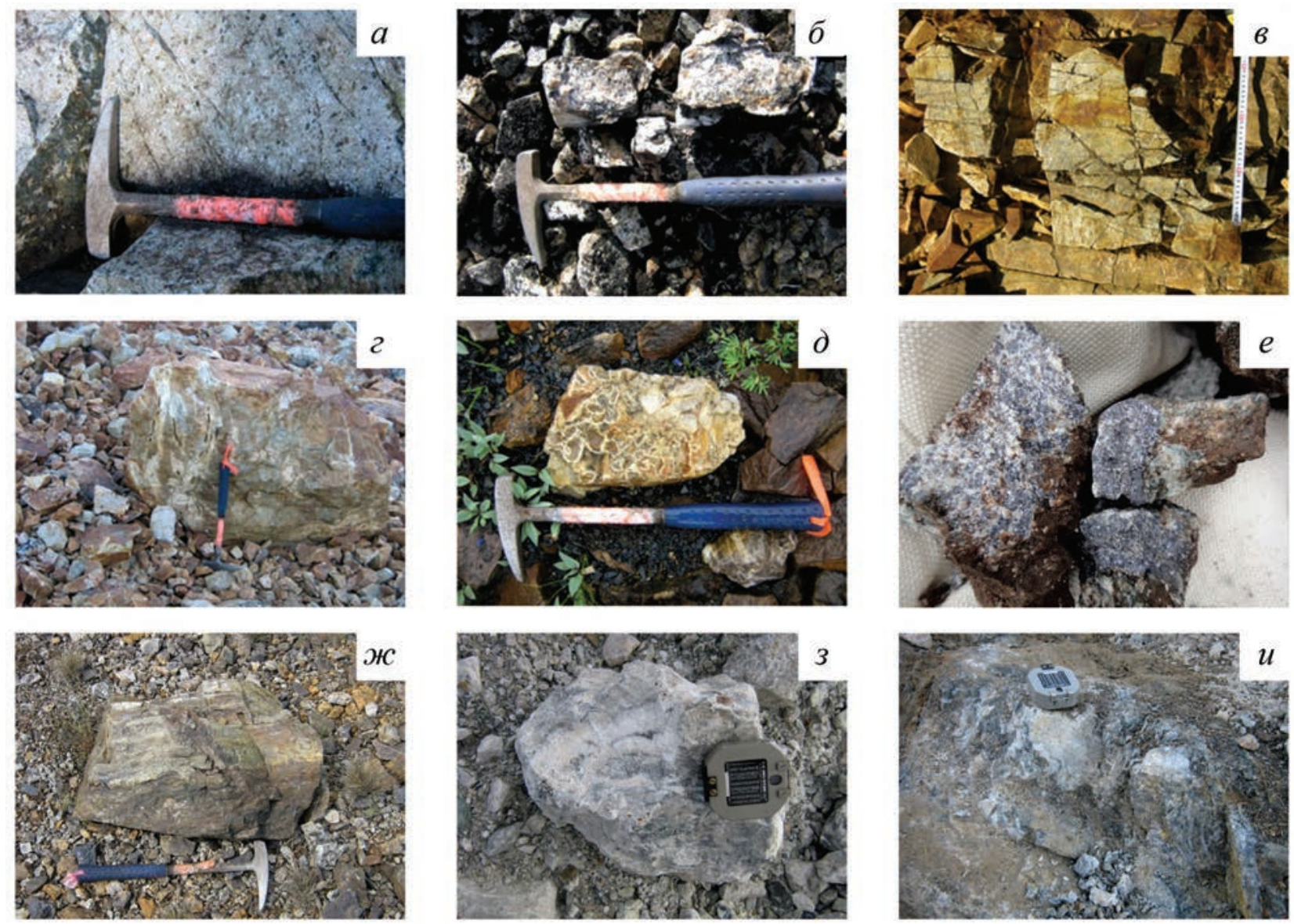

Puc. 3. Руды Омолонского террейна в естественном залегании и штуфах: Табор-Орлиное рудное поле, кварцсульфидный штокверк с медной минерализацией $(a)$; Табор-Орлиное рудное поле, жила с золото-сереброполиметаллической минерализацией (б); Захаренковское рудное поле, кварц-сульфидный штокверк с медномолибденовой минерализацией (в); Захаренковское рудное поле, прожилки с золото-серебро-полиметаллической минерализацией (2); рудопроявление Джелты, жила с золото-серебро-полиметаллической минерализацией ( $\partial$ ); рудопроявление Вулкан, жила с серебро-полиметаллической минерализацией (e); рудопроявление Седое, скарн с полиметаллической минерализацией (ж); месторождения Биркачан (з) и Нижний Биркачан $(u)$, карбонатадуляр-кварцевые жилы с золото-серебряной минерализацией $(u)$

Fig. 3. Ores of the Omolon terrane in natural occurrences and bore holes: Tabor-Orlinoye ore field, quartz-sulfide stockwork with copper mineralization $(a)$; Tabor-Orlinoye ore field, vein with gold-silver-polymetallic mineralization (б); Zakharenko ore field, quartz-sulfide stockwork with copper-molybdenum mineralization (b); Zakharenko ore field, veinlets with gold-polymetallic mineralization (2); Jelty ore occurrence, vein with gold-silver-polymetallic mineralization $(\partial)$; Vulkan ore occurrence, vein with silver-polymetallic mineralization $(e)$; Sedoye ore occurrence, skarn with polymetallic mineralization (ж); Birkachan deposit, carbonate-adularia-quartz vein with gold-silver mineralization (3); Nizhny Birkatchan deposit, carbonate-adularia-quartz vein with gold-silver mineralization $(u)$

ленит, халькопирит, блеклую руду и низкопробное (613-732\%) самородное золото (Глухов и др., 2021).

С медно-молибденовым рудопроявлением Хрустальное ассоциируют железорудные скарны (Фадеев, 1974). Они развиты по рифейским карбонатным отложениям и представлены залежами гранат-пироксен-магнетитового состава с содержаниями железа 20-58 \% и золота до $0.3 \Gamma / \mathrm{T}$.

На восточном фланге ОМ оруденение позднемезозойской медно-молибден-порфировой формации ассоциирует с гранитоидными интрузиями намындыканского комплекса ОВП (Мерзля- ков и др., 1984). Здесь, в пределах Бургагчанского рудного узла, аналогично Табор-Орлиному и Захаренковскому рудным полям, меде- и молибденоносные штокверки и скарны (Медь-Гора) по латерали сменяются жилами с золото-сереброполиметаллической минерализацией (Кэн-Карлик, Извилистое; Кузнецов, 2005).

Оруденение золото-серебряной формацุии является наиболее важным в экономическом отношении на ОМ. Позднепалеозойские месторождения сгруппированы в два рудных района (Кубакинский, Кедонский) и один изолированный рудный узел (Хебикенджинский). Об их возрасте многие годы ведется дискуссия. Существуют точ- 
ки зрения о его дораннекарбоновом (Степанов и др., 1998; Котляр, 2000) или позднемезозойском возрасте (Лейер, 1997; Наталенко и др., 2002). Нами получены данные о возрасте руд и вмещающих их магматических пород (Акинин и др., 2020), указывающие как минимум на карбоновый верхний предел возраста золото-серебряной минерализации. Общими для всех этих месторождений и рудопроявлений являются следующие особенности. Рудные тела представлены крутопадающими карбонат-адуляр-кварцевыми жилами и жильно-прожилковыми зонами (рис. 3, 3, u). Специфической особенностью руд является низкая сульфидность, не превышающая 1-3\%, а для наиболее крупных месторождений (Биркачан, Кубака) составляющая 0.1-0.5\% (Волков и др., 2016). Список рудных минералов, помимо полисульфидов, селенидов и сульфосолей серебра, включает также алтаит и гессит (Савва, 2018). Главными минералами продуктивного парагенезиса являются самородное золото и электрум; роль сульфосолей серебра незначительна. Характерно высокое золото-серебряное отношение (2:1-1:4). Руды содержат значимые (до десятков г/т) количества Те и $\mathrm{Se}$; в их геохимическом спектре (Au-Ag-(As, Sb)-(Mo, W) cyщественную роль играют молибден и вольфрам. Несколько особняком находятся рудопроявления Кедонского рудного района (Юное, Туманное, Рыжик, Риф), которым присущи более низкие золото-серебряные отношения $(1: 10-1: 20)$. Следует выделить месторождение Прогнозное, которое характеризуется своеобразием геологического строения и состава руд (Савва и др., 2014; Волков и др., 2018). Здесь рудные тела представлены зонами кварцевых прожилков с баритом и гематитом и содержат крайне мало сульфидов (менее $0.2 \%$ ): халькопирит, галенит, пирит, арсенопирит галенит, стибнит, леллингит. Геохимический спектр руд Прогнозного $\mathrm{Au}-\mathrm{Ag}-\mathrm{Sb}-\mathrm{W}-\mathrm{As}-\mathrm{Mo}-\mathrm{Zn}$.

Большинство позднемезозойских золотосеребряных месторождений и рудопроявлений, в том числе все промышленные объекты этой группы, сконцентрированы на южной окраине OM, в пределах Туромчинской вулканоструктуры Пенжинского сегмента ОЧВП. Это месторождения и рудопроявления Эвенского рудного района (Ирбычан, Сопка Кварцевая, Ороч, Невенрекан). Они достаточно полно охарактеризованы в литературе (Горячев и др., 2017; Савва, 2018; Прийменко и др., 2020) и имеют достоверно определенный как геологическими данными, так и изотопными $\mathrm{Rb}-\mathrm{Sr}$, K-Ar и $\mathrm{Ar}-\mathrm{Ar}$ датировками позднемеловой возраст (Гундобин и др., 1980; Лейер и др., 1997; Ньюберри и др., 2000; Кравцова и др., 2009). Геохимический спектр руд этих месторождений $\mathrm{Ag}-\mathrm{Au}-(\mathrm{As}, \mathrm{Sb})-(\mathrm{Cu}, \mathrm{Pb}, \mathrm{Zn})$. Их геологическое строение и состав руд близки таковым других месторождений ОЧВП, таких как Карамкен, Купол, Валунистое.

Сульфидность руд, золото-серебряное отношение, геохимический спектр руд наряду с петрохимическими особенностями рудовмещающих вулканитов определяют отличия позднемезозойского золото-серебряного оруденения ОМ от палеозойского (табл. 3). Это напрямую отражается на технологических свойствах руд: палеозойские руды перерабатываются по технологии CIP («уголь в пульпе»), ориентированной на извлечение только золота, а мезозойские Мэррил-Кроу, которая позволяет получать также и серебро.

Определенной спецификой характеризуется позднемезозойское золото-серебряное оруденение Конгинской зоны ОЧВП (Глухов и др., 2021). В одном случае оно ассоциирует с медномолибден-порфировой минерализацией (Захаренковское рудное поле), а в других (Джелты; рис. $3, \partial)$ - относится к типу «Intermediate Sulfidation» (Sillitoe, Hedenquist, 2003) (IS). Главные отличительные черты подобного рода объектов: ассоциация с вулканитами и субвулканическими телами кислого-среднего состава, широкое развитие карбонатов и $\mathrm{Cu}-\mathrm{Pb}-\mathrm{Zb}$ минералов в рудах, низкое отношение $\mathrm{Au} / \mathrm{Ag}(1: 10-1: 100)$.

Рудопроявления серебро-полиметаллической формации также приурочены к ОЧВП и часто пространственно сближены с золото-серебряными. В пределах Конгинской зоны они ассоциируют с гранитоидами викторинского комплекса, имеющими U-Pb возраст по циркону (TIMS) 86-87 млн лет (Глухов и др., 2021), и представлены сульфидно-карбонатными жилами и прожилками и оруденелыми скарнами (рис. $3, e$, ж). Примером являются рудопроявления Седое (Глухов и др., 2021) и Хивач (Болдырев, Яранцева, 1991). На рудопроявлениях Эвенского рудного района (Дручак, Радуга) сульфидно-карбонат-кварцевые прожилки с серебро-полиметаллической минерализацией рассекают пропилитизированные эффузивные породы. Содержания серебра в рудах всех этих объектов достигают 700 г/т, золота - 2 г/т, свинца и цинка $-10 \%$, марганца $-1 \%$.

\section{ОБСУЖДЕНИЕ}

Как уже отмечалось (Глухов, 2019), для ОМ характерна исключительно минерализация жильно-прожилкового типа, контролируемая крутопадающими структурами. Реже встречающиеся оруденелые скарны также имеют крутое падение и часто контролируются теми же структурами, что и жилы. Стратиформная минерализация на ОМ развита крайне незначительно. Объяснение этому заключается в особенностях тектоники террейна. 


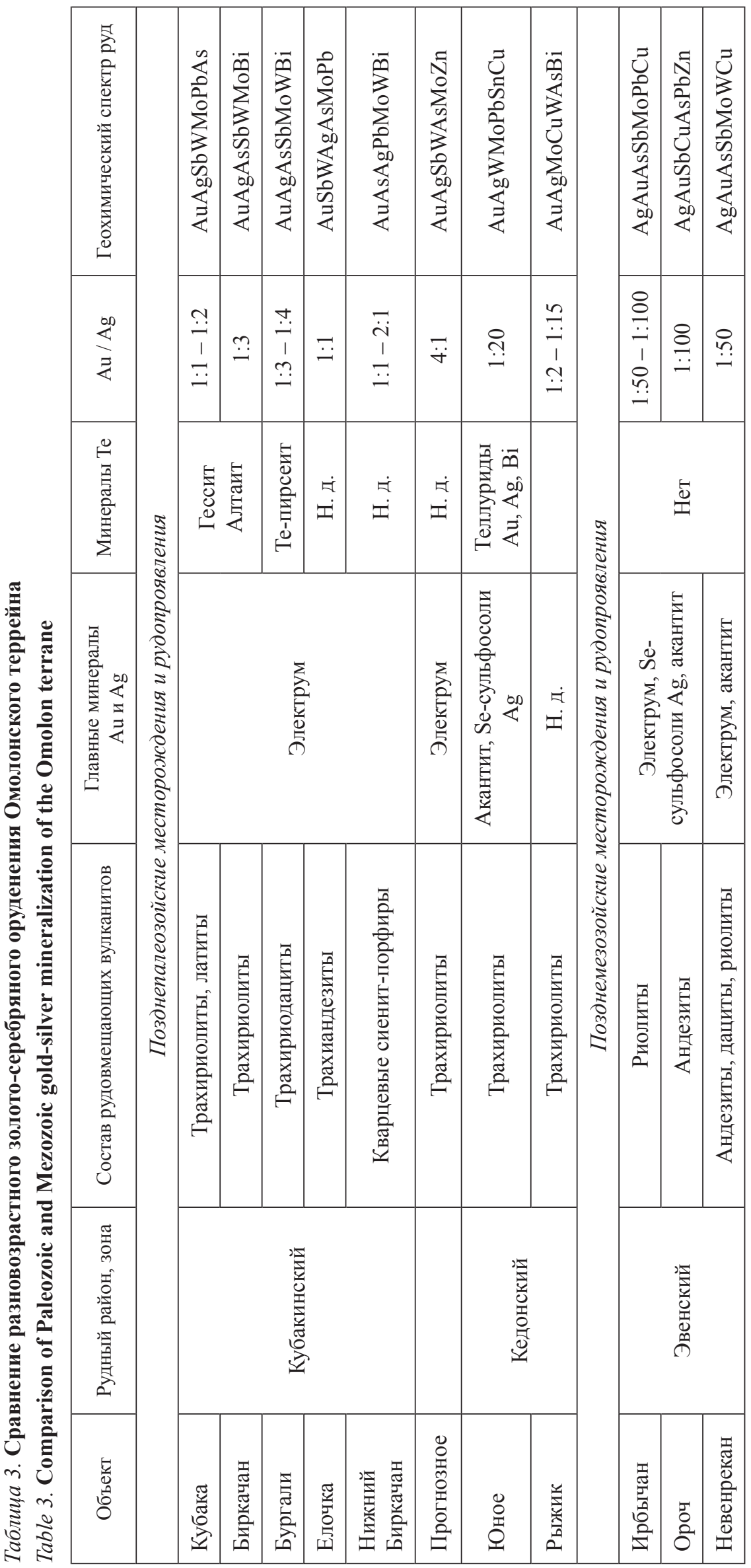


Таблица 4. Изотопный состав серы рудных минералов отдельных месторождений и рудопроявлений Омолонского террейна

Table 4. Isotopic composition of sulfide sulfur of the Omolon terrane ore minerals

\begin{tabular}{|l|l|c|c|c|}
\hline $\begin{array}{c}\text { Месторождение, } \\
\text { рудопроявление }\end{array}$ & \multicolumn{1}{|c|}{ Рудная формация } & Возраст & Минерал & $\mathrm{d}^{34} \mathrm{~S}$ VCDT, \%o \\
\hline Джелты & Золото-серебряная & $\mathrm{K}_{2}$ & Пирит & +0.3 \\
\hline Захаренко & Медно-молибден-порфировая & $\mathrm{K}_{2}$ & Пирит & +4.7 \\
\cline { 3 - 5 } Хрустальное* & $\mathrm{K}_{2}$ & Галенит & +1.8 \\
\hline Нодди* & Молибденит-кварцевая & $\mathrm{PZ}_{1}$ & Молибденит & +2.1 \\
\hline Нодди* & Золото-редкометалльная & $\mathrm{PZ}_{1}$ & Галенит & $-11.9 . .-14.0$ \\
\hline
\end{tabular}

*Горячев и др., 2017.

Структуру его дорифейского метаморфического фундамента определяют моноклинали, сложенные гранулитами, и гранито-гнейсовые купола (Жуланова, 1990; Шевченко, 2006). Абсолютное большинство разломов имеют крутое падение, что подтверждается, в частности, данными сейсмической томографии по профилю 2-ДВ (Мигурский и др., 2007). К примеру, ВерхнеОмолонский глубинный разлом, контролирующий размещение палеозойских интрузий, образован крутопадающими (30-75 $)$ взбросами и сдвигами, образующими зону протяженностью более 100 и шириной до 15 км; суммарная амплитуда вертикального перемещения по ним достигает 2 км (Терехов, 1979). Взбросы и надвиги известны в южной и западной частях ОМ, но падение их сместителей крутое $\left(40-75^{\circ}\right)$, а амплитуды смещения невелики (до 2 км). Глубина проникновения крутопадающих разломов на ОМ подчеркивается существованием Хуличанского рифта, в пределах которого, как предполагается, отсутствует кристаллический фундамент (Дылевский, 1977; Сахно, 2001). Все рудные узлы располагаются вблизи участков сгущения крутопадающих глубинных разломов (Мигурский и др., 2007).

Ограниченные по объему данные по изотопии сульфидной серы из руд ОМ показывают различия состава минерализации различных формаций и возрастов (табл. 4). Меловые медномолибден-порфировые и золото-серебряные объекты Конгинской зоны (Глухов и др., 2021) характеризуются преобладанием «утяжеленного» изотопа, что характерно для субдукционных рудно-магматических систем (Грабежев и др., 1989). Напротив, палеозойское золоторедкометалльное оруденение содержит «легкий» изотоп серы, что характерно для подобных объектов Северо-Востока Азии (Тюкова, Ворошин, 2008). Такое разнообразие изотопного состава существенно отличает Омолонский массив от другого смежного террейна с континентальной корой - Приколымского, руды которого содержат исключительно «тяжелую» метеорную серу (Глухов, Бирюков, 2017).

Изученные нами Табор-Орлиное и Захаренковское рудные поля представляют собой полно- проявленные медно-порфировые рудные системы, в центральных частях которых (см. рис. 2) развита штокверковая медно-молибденовая минерализация, а на периферии - жильная золотосеребро-полиметаллическая. Эти же особенности характерны и для Бургагчанского рудного узла (Кузнецов, 2005). В современной отечественной литературе для обозначения подобных образований используется термин «порфировоэпитермальная система» (Николаев и др., 2016). Примечательно, что в пределах всех медномолибден-порфировых рудных полей и узлов ОМ известны небольшие промышленные россыпи золота, что вообще характерно для зон с минерализацией подобного типа на Северо-Востоке, таких как Баимская (Литвиненко, 2008).

Мы считаем нецелесообразным выделение самостоятельной «золото-джаспероидной» формации. Даже краткий анализ литературы показывает, что ее выделение основывается всего на одном (!) признаке - наличии окварцованных известняков (джаспероидов). Сам по себе термин «Джаспероид» носит описательный характер и лишен генетического смысла. Окварцевание известняков, как и любых других пород, может происходить при формировании месторождений самых разных генетических типов и при разных геологических процессах. В отечественной литературе термин «джаспероидное оруденение» («джаспероидная формация» и т. д.) часто некорректно используют применительно к телетермальным сурьмяно-ртутным месторождениям (например, Хайдаракан) и к золотым месторождениям «типа Карлин». На рудопроявлениях Риф и Ягельное, которые упоминаются как «золотоджаспероидные» (Волков и др., 2011; Горячев и др., 2017), золото-серебряная и полиметаллическая минерализация приурочены к жилам и прожилковым зонам адуляр-кварцевого состава. Окварцованные известняки вблизи жил присутствуют, но содержания золота и серебра в них низкие и не превышают 0.4 и 5 г/т соответственно (Ю. Ф. Файзуллин, 1987 г.; Д. В. Бондарчук, 2014 г.).

Своеобразие геологического строения и состава руд золото-серебряного месторождения 
Прогнозное дало основание Н. Е. Савве с соавторами (Савва и др., 2014; Волков и др., 2018) отнести минерализацию к кластогенной, образованной за счет золота, поступившего из докембрийских железистых кварцитов. По нашему мнению, для объяснения состава руд Прогнозного нет никакой необходимости строить экзотические гипотезы. Убогая сульфидность руд и высокое золотосеребряное отношение являются характерными для всей позднепалеозойской золото-серебряной формации ОМ. Геохимический спектр руд Прогнозного аналогичен спектрам Кубаки, Биркачана и других месторождений КВП (см. табл. 3).

Следует рассмотреть вопрос о «сереброарсенидной формации» ОМ, к которой Н. Е. Савва относила серебро-полиметаллические рудопроявления Седое и Правое Визуальное (Савва, Ведерников, 1989; Савва, 2018, 2019), параллелизуя их с так называемой пятиметалльной (Ag-BiCo-Ni-As) рудной формацией (Bastin, 1939; Антонов, 1992). По нашему мнению, для этого нет достаточных оснований. «Пятиметалльная» рудная формация, помимо совершенно иных условий локализации, морфологии и состава рудных тел, содержит другой набор минералов Ni и Со и имеет ряд других специфических черт, не присущих месторождениям Северо-Востока Азии в целом (Franklin et al., 1986; Борисенко и др., 1992; Burish et al., 2017). В частности, можно упомянуть ее тесную связь с щелочнобазитовым магматизмом. На ОМ щелочные базальты и комагматичные им дайки щелочных габброидов распространены достаточно широко и имеют возраст от позднего триаса до раннего мела (Горячев и др., 2017). Однако они тяготеют преимущественно к восточному флангу массива, а вовсе не к Конгинской зоне, в пределах которой щелочные базиты встречаются крайне редко. Какая-либо минерализация, ассоциирующая с этими образованиями, неизвестна. Щелочные базиты палеозойского возраста в регионе неизвестны; существование в эту эпоху на ОМ благоприятных для их формирования рифтогенных обстановок ничем не подтверждено. В рудах Седого отсутствует сидерит, типоморфный для «пятиметалльной» формации; минералы As, Ni и Со здесь отлагались в позднюю стадию, в то время как для Ag-Sb месторождений As-Ni-Co ассоциация является наиболее ранней (Борисенко и др., 1992). Минералы Ві и самородное Ag присутствуют также на скарновом $\mathrm{Ag}-\mathrm{Pb}-\mathrm{Zn}$ рудопроявлении Хивач в южной части Конгинской зоны (Болдырев, Яранцева, 1991) и вообще характерны для многих скарновых $\mathrm{Pb}$ Zn объектов (Добровольская, 1987; Симаненко, Раткин, 2006). Геохимический спектр рудопроявления Седое аналогичен и спектрам сереброполиметаллических объектов Конгинской зоны, и прилегающего к ОМ сектора ОЧВП; концен- трации $\mathrm{Ni}, \mathrm{Co}, \mathrm{Bi}$ в рудах низкие и не превышают 100 г/т. Это совершенно не характерно для «пятиметалльной» формации. В то же время леллингит, кобальтин и глаукодот в ассоциации с золотом и минералами Ві и Те обычны для связанного с гранитоидами золото-редкометалльного оруденения. По нашему мнению, рудопроявление Седое относится к группе контактовометасоматических скарново-рудных систем (Синяков, 1990). На серебро-полиметаллическую наложена более поздняя $\mathrm{Au}-\mathrm{Bi}$ (As, Ni, Co) минерализация, связанная с гранитоидами завершающей фазы викторинского комплекса.

Ранее нами было рассмотрено влияние тектоники и геодинамической эволюции на продуктивность золотых руд и россыпей ОМ (Глухов, 2020). Был сделан вывод о том, что продуктивность золоторудно-россыпных узлов находится в зависимости от наличия консолидированного дорифейского фундамента. Данная зависимость реализуется через морфологию и условия залегания рудных тел и рудоконтролирующих разломов, глубину их проникновения, спектр геологогенетических типов минерализации и ее богатство. Теперь мы приходим к выводу, что данная закономерность касается не только руд золота, но и цветных металлов. Глыбовая тектоника ОМ определила также относительно малое (по сравнению с Приколымским; Глухов, 2019) число этапов рудогенеза и их высокую интенсивность (формирование большого числа месторождений, включая крупные по запасам). Тяготение крупных месторождений золота, цветных металлов, урана к глубинным разломам, рассекающим жесткие консолидированные структуры с докембрийским фундаментом и значительной ( > 100 км) мощностью литосферы, является известным фактом (Малышев и др., 2004). В первом приближении те же основные черты тектоники и металлогении характерны и для другого кратонного террейна Северо-Востока Азии - Охотского (Геодинамика..., 2006).

\section{ЗАКЛЮЧЕНИЕ}

Разнообразные месторождения и рудопроявления $\mathrm{Au}, \mathrm{Ag}, \mathrm{Cu}, \mathrm{Pb}, \mathrm{Zn} \mathrm{OM}$ подразделяются нами на четыре рудные формации: золото-редкометалльную, золото-серебряную, медно-молибден-порфировую и серебро-полиметаллическую. За исключением последней, все они повторялись на протяжении двух этапов рудогенеза - средне-, позднепалеозойского и позднемезозойского, отражая цикличность металлогенической эволюции террейна, обусловленную насыщенными событиями историю геодинамического развития восточной окраины СевероАзиатского кратона. Достаточно узкий спектр рудных формаций ОМ объясняется влиянием 
тектоники террейна. Он является жесткой глыбовой структурой с консолидированным дорифейским фундаментом, несогласно перекрывающим его осадочным чехлом, блоковым типом деформаций и отсутствием складок и надвигов. Ранняя консолидация привела, с одной стороны, к сужению спектра магматических и рудных формаций, а с другой - формированию крупных по запасам и прогнозным ресурсам месторождений. Этой же причиной обусловлено формирование сквозных крупных глубинных разломов, таких как Конгинская зона (Глухов и др., 2021), по которым наложенные тектоно-магматические и рудные процессы проникали далеко в глубь террейна.

\section{ЛИТЕРАТУРА}

Акинин В. В., Глухов А. Н., Котов А. Б., Альшевский А. В., Прийменко В. В., Ползуненков Г. О. Новые данные о возрасте Кедонского вулканического пояса Омолонского массива (Северо-Восток Азии) // Фундаментальные проблемы тектоники и геодинамики : Материалы 52-го Тектонического совещания. Москва : Геос, 2020. Т. 1. С. 175-177.

Алексеенко А. В., Коробейников С. В., Сидоров B. $A$. Новые данные о медно-молибден-порфировом оруденении в пределах Омолонского массива // Рудные формации Северо-Востока СССР. Магадан : СВКНИИ ДВО АН СССР, 1990. С. 157-162.

Антонов A. Е. Зарубежные месторождения серебра. Москва : Недра, 1992. 254 с.

Болдырев М. В., Яранцева Л. М. Хивачское рудное поле - один из нетрадиционных для Северо-Востока типов серебро-полиметаллического оруденения // Материалы по геологии и полезным ископаемым СевероВостока СССР. Магадан : Кн. изд-во, 1991. Вып. 27. C. $276-278$.

Борисенко А. С., Павлова Г. Г., Оболенский А. А. Серебро-сурьмяная рудная формация. Ч. 1. Геология, минералогия, эндогенная зональность оруденения. Новосибирск : Наука, 1992. 189 с.

Волков А. В., Савва Н. Е., Мурашов К. Ю. Геохимические особенности руд Прогнозного месторождения (Хивачский выступ Омолонского массива) // Геология и минерально-сырьевые ресурсы Северо-Востока России : Материалы VIII Всерос. науч.-практ. конф., 18-20 апр. 2018 г.; в 2 т. Якутск : Издат. дом СВФУ, 2018. T. 1. C. $30-32$.

Волков А. В., Савва Н. Е., Сидоров А. А. Металлогения золота и серебра Кедонского $\left(\mathrm{D}_{2-3}\right)$ вулканоплутонического пояса (Северо-Восток России) // Доклады Академии наук. 2011. Т. 439, № 5. С. 633-640.

Волков А. В., Сидоров А. А., Савва Н. Е., Прокофьев В. Ю., Колова Е. Е., Мурашов К. Ю., Земскова $M$. И. Особенности эпитермального рудообразования в Кедонском палеозойском вулканоплутоническом поясе Северо-Востока России, по данным геохимических исследований $\mathrm{Au}-\mathrm{Ag}$ оруденения // Вулканология и сейсмология. 2016. № 6. С. 3-21. DOI: 10.7868/ S0203030616060079

Гамянин Г. Н. Минералого-генетические аспекты золотого оруденения Верхояно-Колымских мезозоид. Москва : Геос, 2001. 222 с.
Геодинамика, магматизм и металлогения Востока России : в 2-х кн. / под ред. А. И. Ханчука. Владивосток : Дальнаука, 2006. Кн. 1. С. 1-572. Кн. 2. С. 573-981.

Глухов A. Н. Тектонические факторы рудогенеза докембрийских террейнов на примере Приколымского поднятия и Омолонского массива (СевероВосток Азии) // Вестник СПбГУ. Науки о Земле. 2019. Т. 64. Вып. 2. С. 219-248. DOI: 10.21638/ spbu07.2019.204

Глухов A. Н. Продуктивность золоторудно-россыпных узлов Омолонского и Приколымского террейнов (Северо-Восток Азии) // Вестник СевероВосточного научного центра ДВО РАН. 2020. № 3. C. 11-27. DOI: 10.34078/1814-0998-2020-3-11-27

Глухов А. Н., Бирюков А. А. Факторы геохимической специализации эпигенетического оруденения докембрийских террейнов на примере Северо-Востока Азии // Основные проблемы в учении об эндогенных рудных месторождениях: новые горизонты : сб. материалов Всерос. конф., посвящ. 120-летию со дня рождения выдающегося российского ученого академика А. Г. Бетехтина. Москва, 20-22 ноября 2017 г. Москва : ИГЕМ РАН, 2017. С. 81-83.

Глухов А. Н., Прийменко В. В., Фомина М. И., Акинин $B$. В. Металлогения Конгинской зоны Омолонского террейна (Северо-Восток Азии) // Вестник СевероВосточного научного центра ДВО РАН. 2021. № 2. C. 3-16.

Горячев Н. А. Происхождение золото-кварцевых жильных поясов Северной Пацифики. Магадан : СВКНИИ ДВО РАН, 2003. 143 с.

Горячев Н. А. Золоторудообразующие системы орогенных поясов // Вестник Северо-Восточного научного центра ДВО РАН. 2006. № 1. С. 2-16.

Горячев Н. А., Егоров В. Н., Савва Н. Е., Кузнецов В. М., Фомина М. И., Рожков П. Ю. Геология и металлогения фанерозойских комплексов юга Омолонского массива. Владивосток : Дальнаука, 2017. 312 с.

Грабежев А. И., Сотников В. И., Чамухина В. А. Изотопный состав серы сульфидов медно-порфировых месторождений Урала // Геохимия. 1989. № 10. C. 1508-1511.

Гундобин Г. М., Захаров М. Н., Смирнов В. Н., Кравияова Р. Г. Новые данные по геохронологии магматических формаций Эвенской вулканической зоны Охотско-Чукотского пояса и связанной с ними рудной минерализации // Геохронология гранитоидов Монголо-Охотского пояса. Москва : Наука, 1980. C. 145-156.

Добровольская М. Г. Генетические особенности свинцово-цинковых месторождений в карбонатных породах и скарнах // Построение моделей рудообразующих систем. Новосибирск : Наука, 1987. С. 141151.

Дылевский Е. Ф. Меловые вулканогенные образования Омолонского массива и их петрохимические особенности // Вопросы геологии срединных массивов Северо-Востока СССР. Магадан : СВКНИИ ДВНЦ АН СССР, 1977. Вып. 77. С. 104-119.

Жуланова И. Л. Земная кора Северо-Востока Азии в докембрии и фанерозое. Москва : Наука, 1990. 304 c.

Колесников Д. И., Розинов М. И., Шатков Н. Г. Признаки сереброносности вулканических структур 
Охотско-Чукотского пояса // Тихоокеанская геология. 1999. Т. 18, № 4. C. 67-78.

Константинов М. М., Политов В. К., Стружков С. Ф., Аристов В. В., Вакин М. Е., Рыжсов О. Б. Омолонский золотоносный регион и его перспективы // Проблемы геологии и металлогении Северо-Востока Азии на рубеже тысячелетий: в 3-х т. Материалы 11-й сессии Северо-Восточного отделения ВМО «Регион. науч.-практ. конф., посвящ. 100-летию со дня рожд. Ю. А. Билибина» (Магадан, 16-18 мая 2001 г.). Магадан : СВКНИИ ДВО РАН, 2001. Т. 2. С. 94-98.

Кораго Е. А. Кристаллокластические игнимбриты северо-западной окраины Омолонского массива // Геология и геофизика. 1977. № 7. С. 35-46.

Кораго Е. А., Лычагин П. П. Особенности среднепалеозойских вулканитов Омолонского массива и перспективы связанного с ним медно-молибденового оруденения // Вопросы геологии срединных массивов Северо-Востока СССР. Магадан : СВКНИИ ДВНЦ AH CCCP, 1977. С. 99-103.

Котляр И. Н. Возраст золотых руд месторождения Кубака // Магматизм и метаморфизм Северо-Востока Азии : Материалы IV регионального петрографического совещания по Северо-Востоку России. Магадан : СВКНИИ ДВО РАН, 2000. С. 156-159.

Кравцова Р. Г. Геохимия и условия формирования золото-серебряных рудообразующих систем Северного Приохотья. Новосибирск : Геос, 2010. 292 с.

Кравиова Р. Г., Дриль С. И., Алмаз Я. А., Татарников С. А., Владимирова Т. А. Первые данные по Rb$\mathrm{Sr}$ возрасту и изотопному составу золото-серебряных руд месторождения Дальнего (Эвенский рудный район, Северо-Восток России) // Доклады Академии наук. 2009. Т. 428, № 2. С. 240-243.

Кузнецов В. М. Геология и рудоносность Бургачанского мегаузла Омолонской металлогенической провинции // Проблемы геологии и металлогении рудных районов Северо-Востока России : сб. науч. трудов. Магадан : СВКНИИ ДВО РАН, 2005. С. 92-109.

Лейер П. У., Иванов В. В., Раткин В. В., Бандтиен $T$. K. Эпитермальные золото-серебряные месторождения Северо-Востока России: первые ${ }^{40} \mathrm{Ar} /{ }^{39} \mathrm{Ar}-$ определения возраста руд // Доклады АН СССР. 1997. Т. 356, № 5. С. 665-658.

Литвиненко И. С. Весьма мелкое и тонкое золото в россыпях на Северо-Востоке России // Тихоокеанская геология. 2008. Т. 27, № 2. С. 92-106.

Мальшев Ю. Ф., Горошко М. В., Родионов С. М., Романовский Н. П. Глубинное строение и перспективы поисков крупных и сверхкрупных рудных месторождений на Дальнем Востоке // Крупные и сверхкрупные месторождения: закономерности размещения и условия образования. Москва : ИГЕМ РАН, 2004. C. 423-430.

Мерзляков В. М., Дьлевский Е. Ф., Льчагин П. П., Терехов М. И. Тектоника, магматизм и металлогения Омолонского срединного массива // Геология и полезные ископаемые Северо-Востока Азии. Владивосток : ДВНЦ АН СССР, 1984. С. 140-151.

Мигурский А. В., Гошко Е. Ю., Мигурский Ф. А., Соболев П. Н. Геодинамические обстановки в земной коре Северо-Востока России вдоль профиля 2-ДВ (0-1460 км) // Структура и строение земной коры Магаданского сектора России по геолого- геофизическим данным. Новосибирск : Наука, 2007. C. 146-153.

Наталенко М. В., Стружков С. Ф., Рыжсо О. Б., Вакин М. Е., Ииков Б. И., Гиллес Б., Карчавеч В. П., Устинов В. И., Шергина Ю. П. Геологическое строение и минералогия месторождения Биркачан // Руды и металлы. 2002. № 6. С. 37-52.

Николаев Ю. Н., Бакшеев И. А., Прокофьев В. Ю., Нагорная Е. В., Марущенко Л. И., Сидорина Ю. Н., Читалин А. Ф., Калько И. А. Аu-Ag минерализация порфирово-эпитермальных систем Баимской зоны (Западная Чукотка, Россия) // Геология рудных месторождений. 2016. Т. 58, № 4. С. 319-345. DOI: 10.7868/ S001677701604005

Ньюберри Р. Дж., Лейер П. У., Ганз П. Б., Гончаров B. И., Горячев Н. А., Ворошин С. В. Предварительный анализ хронологии мезозойского магматизма, тектоники и оруденения на Северо-Востоке России с учетом датировок ${ }^{40} \mathrm{Ar} /{ }^{39} \mathrm{Ar}$ и данных по рассеянным элементам изверженных и оруденелых пород // Золотое оруденение и гранитоидный магматизм Северной Пацифики : Труды Всероссийского совещания. Магадан, 4-6 сентября 1997 г. Магадан : СВКНИИ ДВО РАН, 2000. T. 1. С. 181-205.

Павлова И. Г. Медно-порфировые месторождения (закономерности размещения и критерии прогнозирования). Ленинград : Недра, 1978. 275 с.

Пак A. М. Порфировое оруденение Южно-Омолонского рудного района // Колыма. 2002. № 4. С. 14-18.

Петренко И. Д. Золото-серебряная формация Камчатки. Санкт-Петербург : Изд-во ВСЕГЕИ, 1999. 116 с.

Прийменко В. В., Глухов А. Н., Фомина М. И., Михалищьнна Т. И. Интрузивный этап развития вулканоструктуры и $\mathrm{Au}-\mathrm{Ag}$ оруденения на примере месторождения Невенрекан (Магаданская область, Россия) // Вулканология и сейсмология. 2020. № 5. С. 13-25.

Савва Н. Е. Минералогия серебра Северо-Востока России. Москва : Триумф, 2018. 518 с.

Савва Н. Е. Серебро-арсенидная формация Омолонского срединного массива (новые данные) // Вестник Северо-Восточного научного центра РАН. 2019. № 4. C. 9-17. DOI: 10.34078/1814-0998-2019-4-9-17

Савва Н. Е., Ведерников В. Н. Новый тип серебряной минерализации на Северо-Востоке СССР // Геохимия и минералогия рудных месторождений СевероВостока СССР. Магадан : СВКНИИ ДВО АН СССР, 1989. C. 86-97.

Савва Н. Е., Волков А. В., Ииков Б. И., Сидоров $A$. $A$. Модель формирования золото-гематит-баритовой минерализации месторождения Прогнозное // Доклады Академии наук. 2014. Т. 456, № 4. С. 461-464.

Сахно В. Г. Позднемезозойско-кайнозойский континентальный вулканизм Востока Азии. Владивосток : Дальнаука, 2001. 335 с.

Сидоров А. А., Волков А. В., Алексеев В. Ю. О металлогении кратонных террейнов и «районов пологих дислокаций» на Северо-Востоке России // Доклады Академии наук. 2008. Т. 423, № 5. С. 783-787.

Симаненко Л. Ф., Раткин В. В. Партизанское скарново-полиметаллическое месторождение: геология, минералогия, генезис (Таухинская металлогеническая зона, Сихотэ-Алинь). Москва : Наука, 2006. 158 с.

Синяков В. И. Генетические типы скарновых рудообразующих систем. Новосибирск : Наука, 1990. 71 с. 
Соколов С. Д. Очерки тектоники Северо-Востока Азии // Геотектоника. 2010. № 6. С. 60-78.

Сотников В. И. Медно-молибден-порфировая рудная формация: природа, проблема объема и границ // Геология и геофизика. 2006. Т. 47, № 3. С. 355-363.

Степанов В. А., Шергина Ю. П., Шишакова Л. Н., Шкорбатова Г. С., Рублев А. Г. Возраст руд Кубакинского месторождения золота (Омолонский массив) // Тихоокеанская геология. 1998. Т. 17, № 5. С. 89-97.

Строна П. А. Главные типы рудных формаций. Ленинград : Недра, 1978. 199 с.

Терехов М. И. Стратиграфия и тектоника южной части Омолонского массива. Москва : Наука, 1979. $116 \mathrm{c}$.

Тюкова Е. Э., Ворошин С. В. Изотопный состав серы в сульфидах руд и вмещающих пород ВерхнеКолымского региона // Тихоокеанская геология. 2008. T. 27, № 1. C. 27-43.

Фадеев А. П. Магнетитовые скарны ручья Хрустального (Омолонский массив) // Материалы по геологии и полезным ископаемым Северо-Востока СССР. Магадан : Кн. изд-во, 1974. Вып. 21. С. 319-321.

Шевченко В. М. Архей и протерозой Омолонского массива. Петрология и изотопный возраст. Магадан : СВНЦ ДВО РАН, 2006. 176 с.

Шиикерман В. И. Домеловая минерагения СевероВостока Азии. Магадан : СВКНИИ ДВО РАН, 1998. $333 \mathrm{c}$.

Шпикерман В. И., Горячев Н. А., Егоров В. Н. О силурийском тектогенезе, магматизме и метаморфизме на Северо-Востоке Азии // Проблемы геологии и металлогении Северо-Востока Азии на рубеже тысячелетий. Магадан : СВКНИИ ДВО РАН, 2001. Т. 1. C. $102-103$.
Шульгина В. С., Кузнецов В. М., Нефедова И. Я., Ичетовкин Н. В. Государственная геологическая карта СССР. Масштаб 1:1 000000 (новая серия). Лист Q-56, -57 (Средне-Колымск). Полезные ископаемые : объяснительная записка. Ленинград : ВСЕГЕИ, 1993. $65 \mathrm{c}$.

Bastin E. S. The nickel-cobalt-native silver ore type // Economic Geology. 1939. Vol. 34. P. 1-40.

Burish M., Gerdes A., Walter B., Neumann U., Fettel M., Markl G. Methane and the origin of five-element veins: Mineralogy, age fluid inclusion chemistry and ore forming processes in the Odenwald // Ore Geology Reviews. 2017. Vol. 81. P. 42-61.

Franklin J. M., Kissin S. A., Smyk M. C., Scott S. D. Silver deposits associated with Proterozoic rocks of the Thunder Bay District, Ontario // Canadian Journal of Earth Sciences. 1986. Vol. 23. P. 1576-1591.

Groves D. I., Goldfarb R. J., Robert F., Hart C. J. R. Gold deposits in metamorphic belts: Overview of current understanding, outstanding problems, future research, and exploration significance // Economic Geology. 2003. Vol. 98. P. 1-31.

Hedenquist J. W., Arribas A. R., Gonzalez-Urien E. Exploration for epithermal gold deposits // SEG Reviews. 2000. Vol. 13. P. 245-277.

Ludington S., Plumlee G. S. Climax-type porphyry molybdenum deposits. USGS Open-File Report 2009$1215.16 \mathrm{p}$.

Sillitoe R. H. Porphyry copper systems // Economic Geology. 2010. Vol. 105. P. 3-41.

Sillitoe R. H., Hedenquist J. W. Linkages between volcanotectonic setting, ore-fluid composition, and epitermal precious metal deposits // SEG Special Publication. 2003. Vol. 10. P. 315-343.

Поступила в редакичию 17.02.2021 2.

Поступила после доработки 09.07.2021 2.

\title{
ON THE ISSUE OF ORE FORMATIONS OF PRECIOUS AND BASE METALS OF THE OMOLON TERRANE (North-East Asia)
}

\section{A. N. Glukhov}

\author{
North-East Interdisciplinary Scientific Research Institute n. a. N. A. Shilo, FEB RAS, Magadan
}

The author characterizes gold, silver, copper, lead, and zinc deposits developed within the Omolon craton terrane. Outlined are ore formations (genetic types) including the deposits. The principal features of the terrane metallogeny terrane are shown as determined by the stable structure of the crystalline basement, consolidated in Early Precambrian, which resulted in contraction of the range of mineralization genetic types and in formation of deep ore- and magma-controlling faults and large deposits.

\section{Keywords: craton terrane, metallogeny, ore formation, basement, consolidated.}




\section{REFERENCES}

Akinin, V. V., Glukhov, A. N., Kotov, A. B., Alsheysky, A. V., Priymenko, V. V., Polzunenkov, G. O., 2020. The New Data on the Age of the Kedon Volcanic Belt in the Omolon Massif (Northeast Asia), The Fundamental Problems of Tectonics and Geodynamics, Proceedings of the $52^{\text {nd }}$ Tectonic Conference. Moscow, GEOS. 1, 175-177 [In Russian].

Alekseyenko, A. V., Korobeynikov, S. V., Sidorov, V. A., 1990. The New Data on Porphyry-Copper Mineralization at the Omolon Massif, Ore Formation of the North-East of the USSR. Magadan, SVKNII DVO AN USSR. 157162 [In Russian].

Antonov A. E., 1992. Foreign Silver Deposits. Moscow, Nedra [In Russian]

Bastin E. S., 1939. The Nickel-Cobalt-Native Silver Ore Type, Economic Geology. 34, 1-40.

Boldyrev, M. V., Yarantseva, L. M., 1991. Khivach Ore Field: One of Silver-Lead-Zinc Mineralization Types Untypical for the North-East, Materials on Geology and Mineral Resources of the USSR North-East. Magadan. 27, 276-278 [In Russian].

Borisenko, A. S., Pavlova, G. G., Obolensky, A. A., 1992. Silver-Antimony Ore Formation. Part 1. Geology, Mineralogy, Endogenic Zonation of Mineralization. Novosibirsk, Nauka [In Russian].

Burish, M., Gerdes, A., Walter, B., Neumann, U., Fettel, M., Markl, G., 2017. Methane and the Origin of FiveElement Veins: Mineralogy, Age Fluid Inclusion Chemistry and Ore Forming Processes in the Odenwald, Ore Geology Reviews. 81, 42-61.

Fadeyev, A. P., 1974. Magnetite Skarns of the Khrustalny Creek (Omolon Massif), Materials on Geology and Mineral Resources of the USSR North-East. Magadan. 21, 319-321 [In Russian].

Franklin, J. M., Kissin, S. A., Smyk, M. C., Scott, S. D., 1986. Silver Deposits Associated with Proterozoic Rocks of the Thunder Bay District, Ontario, Canadian Journal of Earth Sciences. 23, 1576-1591.

Gamyanin, G. N., 2001. Mineralogical and Genetic Aspects of Gold Mineralization of the Verkhoyan-Kolyma Mezozoids. Moscow, GEOS [In Russian].

Geodynamics, Magmatism, and Metallogeny of Russia's East: in 2 Books, Ed. A. I. Khanchuk, 2006. Vladivostok, Dalnauka. Book 1, 1-572 [In Russian].

Glukhov, A. N., 2019. Tectonic Factors of Metallogeny of Precambrian Terranes Exemplified by the Kolyma Elevation and the Omolon Massif (North-East of Asia), Vestnik of Saint-Petersburg University. Earth Sciences. 64 (2), 219-248 [In Russian].

Glukhov, A. N., 2020. Productivity of Gold Ore-Placer Clusters of the Omolon and Kolyma Terranes (Northeast Asia), Bulletin of the North-East Science Center. 3, 1, 1-27. DOI: 10.34078/1814-0998-2020-3-11-27 [In Russian].

Glukhov, A. N., Biryukov, A. A., 2017. Factors of Geochemical Specialization of Epigenetic Ores in Precambrian Terranes Exemplified by North-East of Asia, Proceedings of the Conference Dedicated to A. A. Betekhtin. Moscow, November 20-22, 2017. Moscow, IGEM RAS. 81-83 [In Russian].

Glukhov, A. N., Priymenko, V. V., Fomina, M. I., Akinin, $V . V ., 2021$. Metallogeny of the Kongin Zone of the Omolon Terrane (Northeast Asia), Bulletin of the North-
East Science Center. 2, 3-16. DOI: 0.34078/1814-09982021-2-3-16 [In Russian].

Goryachev, N. A., 2003. Origin of Mezozoic GoldQuartz Lode Belts of the North Pacific. Magadan, NEISRI FEB RAS [In Russian].

Goryachev, N. A., 2006. Gold-Ore-Forming Systems of Orogenic Belts, Vestnik NESC FEB RAS. 1, 2-16 [In Russian].

Goryachev, N. A., Egorov, V. N., Savva, N. E., Kuznetsov, V. M., Fomina, M. I., Rozhkov, P. Yu., 2017. Geology and Metallogeny of Phanerozoic Assemblages in the South of the Omolon Microcontinent. Vladivostok, Dalnauka [In Russian].

Grabezhev, A. I., Sotnikov, V. I., Chashchukhina, V. A., 1989. Isotopic Composition of Sulfur from the Urals Porphyry-Copper Deposits, Geochemistry International. 10, 1508-1511 [In Russian].

Groves, D. I., Goldfarb, R. J., Robert, F., Hart, C. J. R., 2003. Gold Deposits in Metamorphic Belts: Overview of Current Understanding, Outstanding Problems, Future Research, and Exploration Significance, Economic Geology. 98, 1-31.

Gundobin, G. M., Zakharov, M. N., Smirnov, V. N., Kravtsova, R. G., 1980. New Data on Geochronology of Magmatic Formations of the Evensk Volcancic Zone in the Okhotsk-Chukotka Belt and Associated Mineralization, Geochronology of the Mongol-Okhotsk Belt Granitoids. Moscow, Nauka. 145-146 [In Russian].

Dobrovolskaya, M. G., 1987. Genetic Features of Lead-Zinc Deposits in Carbonate Rocks and Skarns, Building Models of Ore-Forming Systems. Novosibirsk, Nauka. 141-151 [In Russian].

Dylevsky, E. F., 1977. Cretaceous Volcanogenic Formations of the Omolon Massif and Their Petrochemical Features, Issues in the Geology of Middle Massifs in Russia's North-East. Magadan, SVKNII DVNC AN USSR [In Russian].

Hedenquist, J. W., Arribas, A. R., Gonzalez-Urien, E., 2000. Exploration for Epithermal Gold Deposits, SEG Reviews. 13, 245-277.

Kolesnikov, D. I., Rozinov, M. I., Shatkov, N. G., 1999. Signs of Silver Mineralization in Volcanic Structures of the Okhotsk-Chukotka Belt, Russian Journal of Pacific Geology. 18 (4), 67-78 [In Russian].

Konstantinov, M. M., Politov, V. K., Struzhkov, S. F., Aristov V. V., Vakin M. E., Ryzhov O. B., 2001. Omolon Gold-Bearing District and Its Prospectives, Problems of Geology and Metallogeny of Northeastern Asia at the Boundary of Millennia, Proceedings of $11^{\text {th }}$ Session of North-East Branch of AMC Regional ScientificPractical Conference Devoted to the $100^{\text {th }}$ Birthday of Yu. A. Bilibin (Magadan, May 16-18, 2001). Magadan, NEISRI FEB RAS. 2, 94-98 [In Russian].

Korago, E. A., 1977. Crystalloclastic Ignimbrites of North-West Margin of the Omolon Massif, Sovetskaya Geologiya i Geofizika. 7, 35-46 [In Russian].

Korago, E. A., Lychagin, P. P., 1977. Features of Middle-Paleozoic Volcanites of the Omolon Massif and Perspectives of the Associated Cu-Mo Mineralization, Issues in Geology of Median Massifs in the USSR NorthEast. Magadan, SVKNII DVNC AN USSR. 99-103 [In Russian]. 
Kotlyar, I. N., 2000. Age of Gold Ores at the Kubaka Deposit, Magmatism and Metamorphism in the NorthEast of Asia, Proceedings of the $4^{\text {th }}$ Regional Petrographic Session on Russia's North-East. Magadan, NEISRI FEB RAS. 156-159 [In Russian].

Kravtsova, R. G., 2010. Geochemistry and Conditions of Gold-Silver Ore Formation Systems in the North Priokhotye. Novosibirsk, GEOS [In Russian].

Kravtsova, R. G., Dril', S. I., Almaz, Ya. A., Tatarnikov, S. A., Vladimirova, T. A., 2009. The First Data abot $\mathrm{Rb}-\mathrm{Ar}$ Age and Isotopic Composition of Gold-Silver Ores of the Dalneye Deposit (Evensk Ore District, North-East of the Russia), Doklady Earth Sciences. 428 (2), 240-243 [In Russian].

Kuznetsov, V. M., 2005. Geology and Mineralization of the Burgachan Ore Knot of the Omolon Metallogenic Province, Problems of Geology and Metallogeny of Ore Districts in Russia's North-East. Magadan, NEISRI FEB RAS. 92-109 [In Russian].

Layer P. U., Ivanov V. V., Ratkin V. V., Bundtzen T. K., 1997, The Epithermal Gold-Silver Deposits of NorthEast of the Russia: First ${ }^{40} \mathrm{Ar} /{ }^{39} \mathrm{Ar}$ Determinations of Age of the Ores, Doklady Earth Sciences. 356 (5), 665-658 [In Russian].

Litvinenko, I. S., 2008. Essentially Small and Thin Gold in Placers of Northeast Russia, Russian Journal of Pacific Geology. 27 (2), 92-106 [In Russian].

Ludington, S., Plumlee, G. S., 2009-1215. Climaxtype Porphyry Molybdenum Deposits. USGS Open-File Report.

Malyshev, Yu. F., Goroshko, M. V., Rodionov, S. M., Romanovskiy, N. P., 2004. Deep Structure and Exploration Perspectives for Large and Superlarge Ore Deposits in the Far East, Large and Superlarge Deposits: Localization Regularities and Formation Conditions. Moscow, IGEM RAS. 423-430 [In Russian].

Merzlyakov, V. M., Dylevsky, E. F., Lychagin, P. P., Terekhov, M. I., 1984. Tectonics, Magmatizm, and Metallogeny of the Omolon Median Massif, Geology and Minerals of Asia's North-East. Vladivostok, DVNZ AN USSR [In Russian].

Migursky, A. V., Goshko, E. Yu., Migursky, F. A., Sobolev, P. N., 2007. Geodynamic Settings in the Earth Crust of Russia's North-East along Profile 2-DV (0-1460 km), Structure of the Earth Crust in the Magadan Sector of Russia, by Geological and Geophysical Data. Novosibirsk, Nauka. 146-153 [In Russian].

Natalenko, M. V., Struzhkov, S. F., Ryzhov, O. B., Vakin, M. E., Ishkov, B. I., Gilles, B., Karchavets, V. P., Ustinov, V. I., Shergina, Yu. P., 2002. Geological Structure and Mineralogy of the Birkachan Deposit, Ores and Metals. 6, 37-52 [In Russian].

Newberry, R. J., Layer, P. U., Ganz, P. B., Goncharov, V. I., Goryachev, N. A., Voroshin, S. V., 2000. Preliminary Analysis of Mezozoic Magmatism Chronology, Tectonics, and Mineralization in Russia's North-East, Considering ${ }^{40} \mathrm{Ar} /{ }^{39} \mathrm{Ar}$ and Trace Element Data for Igneous and Mineralized Rocks, Gold Mineralization and Granitoid Magmatism of the North Pacific. Magadan, NEISRI FEB RAS. 181-205 [In Russian].

Nikolayev, Y. N., Baksheyev, I. A., Marushchenko, L. I., Sidorina, Y. N., Kalko, I. A., Prokofyev, V. Y., Nagornaya,
E. V., Chitalin, A. F., 2016. Gold-Silver Mineralization in Porphyry-Epithermal Systems of the Baimka Zone, Western Chukotka, Russia. Geology of Ore Deposits. 58 (4), 284-307. DOI: 10.7868/S001677701604005

Pak, A. M., 2002. Porphyry Mineralization of the South-Omolon Ore District, Kolyma. 4, 14-18 [In Russian].

Pavlova, I. G., 1978. Copper-Porphyry Deposits: Location Regularities and Predicting Criteria. Leningrad, Nedra [In Russian].

Petrenko, I. D., 1999. Gold-Silver Formation of Kamchatka. Saint-Petersburg, VSEGEI [In Russian].

Priymenko, V. V., Glukhov, A. N., Fomina, M. I., Mikhalitsyna, T. I., 2020. The Intrusive Phase in the Evolution of the Volcanic Structure and of Au-Ag Low Sulfidation Mineralization: The Nevenrekan Deposit, Magadan Region, Russia, Journal of Volcanology and Seismology. 14 (5), 292-304. DOI: 10.1134/S0742046320050048

Sakhno, V. G., 2001. Late Mezozoic and Cenozoic Continental Volcanism of East Asia, Vladivostok, Dalnauka [In Russian].

Savva, N. E., 2018. Mineralogy of Silver in Northeast Russia. Moscow, Triumph [In Russian].

Savva, N. E., 2019. Silver-Arsenide Formation of the Omolon Median Massif (New Data), Bulletin of the NorthEast Science Center. 4, 9-17. DOI: 10.34078/1814-09982019-4-9-17 [In Russian].

Savva, N. E., Vedernikov, V. N., 1989. New Type of Silver Mineralization in the USSR North-East, Geochemistry and Mineralogy of Ore Deposits in the USSR North-East, Magadan, SVRNII DVO AN USSR. 86-97 [In Russian].

Savva, N. E., Volkov, A. V., Sidorov, A. A., Ishkov, B. I., 2014. Model of Formation of Gold-Hematite-Barite Mineralization of the Prognoznoe Deposit, Northeastern Russia, Doclady Earth Sciences. 456 (2), 659-662.

Shevchenko, V. M., 2006. Archean and Proterozoic Rocks of the Omolon Massif - Petrology and Isotope Age. Magadan, NESC FEB RAS [In Russian].

Shpikerman, V. I., 1998. Pre-Cretaceous Metallogeny of Northeastern Asia. Magadan, NEISRI FEB RAS [In Russian].

Shpikerman, V. I., Goryachev, N. A., Egorov, V. N., 2001. Silurian Tectogenesys, Magmatizm and Metamorphizm at the North-East of the Asia, The Problems of Geology and Metallogeny of the North-East of the Asia at New Millenium. Magadan, NEISRI FEB RAS [In Russian].

Shulgina, V. S., Kuznetsov, V. M., Nefedova, I. Ya., Ichetovkin, N. V., 1993. Federal Geological Map of the USSR. 1: 1000000 Scale (New Generation), Q-56, -57, Mineral Resources, Text Report. Leningrad, VSEGEI [In Russian].

Sidorov, A. A., Volkov, A. V., Alekseyev, V. Yu., 2008. On Metallogeny of Craton Terranes and Shallow-Folded Districts in Russia's North-East, Doklady Earth Sciences. 423 (5), 783-787 [In Russian].

Sillitoe, R. H., 2010. Porphyry Copper Systems, Economic Geology. 105, 3-41.

Sillitoe, R. H., Hedenquist, J. W., 2003. Linkages between Volcanotectonic Setting, Ore-Fluid Composition, and Epitermal Precious Metal Deposits, SEG Special Publication. 10, 315-343. 
Simanenko, L. F., Ratkin, V. V., 2006. Partizanskoye Skarn-Polymetallic Deposit: Geology, Mineralogy, Genesis (Taukhin Metallogenic Zone, Sikhote-Alin). Moscow, Nauka [In Russian].

Sinyakov, V. I., 1990. Genetic Types of Skarn OreForming Systems. Novosibirsk, Nauka [In Russian].

Sokolov, S. D., 2010. Tectonics of Northeast Russia: an Overview, Geotectonics. 44 (2), 493-509.

Sotnikov, V. I., 2006. Copper-Molybdenum-Porhyry Ore Formation: Origin, Volume, and Margins, Russian Geology and Geophysics. 47 (3), 355-363 [In Russian]. Stepanov, V. A., Shergina, Yu. P., Shishakova, L. N., Shkorbatova, G. S., Rublyov, A. G., 1998. Age of Ores at the Kubaka Gold Deposit (Omolon Massif), Russian Journal of Pacific Geology. 17 (5), 89-97 [In Russian]. Strona, P. A., 1978. Main Types of Ore Formations. Leningrad, Nedra [In Russian].

Terekhov, M. I., 1979. Stratigraphy and Tectonics of the Southern Part of the Omolon Massif. Moscow, Nauka [In Russian].

Tyukova, Ye. E., Voroshin, S. V., 2008. The Sulfur Isotopic Composition of Sulfides from Ores and Host Rocks of the Upper Kolyma Region, Magadan Oblast. Russian Journal of Pacific Geology. 2 (1), 25-38.

Volkov, A. V., Savva, N. E., Murashov, K. Yu., 2018. Geochemical Features of the Prognoznoye Deposit Ores (Khivach Protrusion, Omolon Massif), Geology and Mineral Resources of North-East of the Russia, Proceedings of the $8^{\text {th }}$ All-Russia Conference. Yakutsk. 1, 30-32.

Volkov, A. V., Savva, N. E., Sidorov, V. A., Sidorov, A. A., 2011. Au and Ag Metallogeny of the Kedon Volcanic-Plutonic Belt $\left(\mathrm{D}_{2-3}\right)$ (Northeast Russia), Doklady Earth Sciences. 439 (2), 1063-1069.

Volkov, A. V., Sidorov, A. A., Savva, N. E., Prokof'ev, V. Yu., Kolova, E. E., Murashov, K. Yu., Zemskova, M. I., 2016. Epithermal Mineralization in the Kedon Paleozoic Volcano-Plutonic Belt, Northeast Russia: Geochemical Studies of Au-Ag Mineralization, Journal of Volcanology and Seismology. 11 (1), 1-19.

Zhulanova, I. L., 1990. Earth Crust of Asia's NorthEast in the Precambrian and Phanerozoic. Moscow, Nauka [In Russian]. 